\section{For spesielt interesserte}

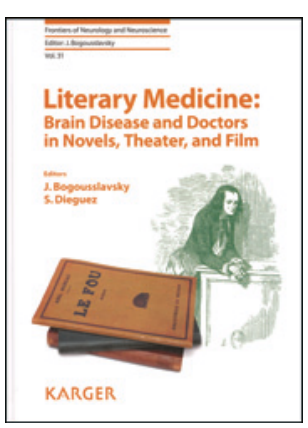

Julien Bogousslavsky,

Sebastian Dieguez, red

Literary medicine

Brain disease and doctors in novels, theater and film. 261 s, tab, ill. Basel: Karger, 2013.

Pris CHF 123

ISBN 978-3-318-02271-1

Literary medicine er ei samling av i alt 19 artiklar kor skribentane tek for seg nevrologiske og psykiatriske sjukdomar, slik desse er blitt skildra i skjønnlitteratur frå 1800-talet og framover. Sjukdomspanoramaet inkluderer tilstandar som også i dag er vanlege, som schizofreni, migrene, alkoholisme og epilepsi. Nokre av artiklane omhandlar meir kulturelt og tidsmessig avgrensa tilstandar, som hysteri, der romanen Emma Bovary av Gustave Flaubert (1821-1880) er trekt fram som eit døme. Tre artiklar tek for seg litterære legeskikkelsar hos forfattarane Marcel Proust (1871-1922), Honoré de Balzac (1799-1850) og Anton Tsjekhov (1860-1904).

Nokre sjukdomar er blitt skildra i litteraturen lenge før diagnosen er blitt etablert og definert innanfor medisinen. Schizofreni er eit døme på ein slik sjukdom. I ein av artiklane tek forfattarane for seg romanen Louis Lambert frå 1833 av den franske forfattaren Honoré de Balzac, der vi finn ei skildring av ein hovudperson som går gjennom alle dei stadier som høyrer med i dei moderne diagnosekriteria for schizofreni. Dette var 69 år før Emil Kraepelin (1856-1926) definerte tilstanden dementia praecox, og 76 år før Eugen Bleuler (1857-1935) innførte namnet schizofreni på denne sjukdomstilstanden.

Forbrytelse og straff av Fjodor Dostojevskij (1821-1881) er eit av dei store verka i verdslitteraturen. Å karakterisere hovudpersonen i romanen, Raskolnikov, som psykopat, som ein av skribentane tek til orde for, er etter mitt syn ei svær forenkling. Forbrytelse og straff er ei stor forteljing som tek for seg sentrale menneskelege problemstillingar innan skyld, straff og soning. Å ta handlingane og reaksjonane til Raskolnikov til inntekt for ei psykopatdiagnose tek bort den allmenne relevansen som denne romanen har.

Boka er av blanda kvalitet etter mitt syn. Mange av artiklane er for spesielt interesserte, og då særskilt innanfor fagfelta nevrologi og psykiatri. Språkleg er den til dels tung å lese. Korleis sjukdom vert framstilt i skjønnlitteraturen, er likevel interessant både i eit medisinsk, historisk og humanistisk perspektiv. Nokre sjukdomar har eksistert berre i gitte tidsepokar, farga av samtida. Seinare kan sjukdomen ha forsvunne eller gitt seg uttrykk i andre former. Dette minner oss på at diagnosar ikkje er hogd i stein.

\section{Lisbeth Homlong}

Institutt for helse og samfunn

Universitetet i Oslo

\section{Dovenskap, uforstand, skjørbuk eller blyforgiftning?}

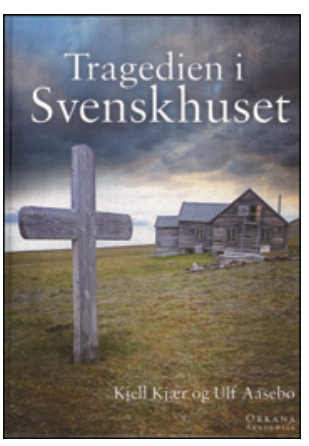

Kjell Kjær, Ulf Aaseb $\varnothing$

Tragedien i Svenskhuset

215 s, ill. Stamsund: Orkana Akademisk, 2012

Pris NOK 279

ISBN 978-82-8104-204-9

Høsten 1872 kom isen uventet tidlig til nordre del av Spitsbergen. Hele 124 personer, fangstfolk og forskere, måtte plutselig erkjenne at de var innesperret og kanskje ikke kunne regne med å komme vekk før sommeren etter. Det ble også fort klart at det ikke var proviant nok til overvintring for alle. Hva skulle de gjøre?

Tilfellet ville at svenske interesser samme år hadde gjort forberedelser til bergverksvirksomhet på Kapp Thordsen i Isfjorden. Blant annet ble det bygd et stort og fint bolighus på Kapp Thordsen. Der var rikelig med proviant, brensel og andre nødvendigheter på plass for vinteren. Så skjedde det bemerkelsesverdige at det på grunn av diverse krangler ble bestemt at virksomheten skulle legges ned før den kom i gang. Alle reiste sin vei.

De innesperrede nord på Spitsbergen visste om dette. Derfor valgte $17 \mathrm{av}$ dem å ta seg frem med to småbåter, $350 \mathrm{~km}$ rundt hele nordvestre del av Spitsbergen og frem til dette såkalte Svenskhuset. 14. oktober 1872 var de ved målet etter en ukes barsk reise. Og i det tomme Svenskhuset ventet mat og varme for lange tider.

I begynnelsen av desember 1872 begynte alle 17 å bli syke, én etter én. 19. februar 1873 døde to av dem. De andre fulgte. Den siste døde sannsynligvis like før det kom folk forbi 15. juni 1873. Huset var da fullt av lik, og det var et fryktelig syn.

Frem til 19. april 1873 foreligger det dagboknotater som med knappe ord forteller om situasjonen. Hva var dette? Tromsø Stiftstidende skrev i juli 1873 at de overvintrende var døde av «Dovenskab og Uforstand». Men det dør man ikke av. At det var skjørbuk, polarstrøkenes tradisjonelle svøpe, ble etter hvert en alminnelig oppfatning. Kunne det stemme?

Forfatterne, historikeren Kjell Kjær og overlege Ulf Aasebø, slo seg ikke til ro med mytene. De gikk til de historiske primærkildene. De fikk også - etter diverse byråkratiske vansker - tillatelse av antikvariske myndigheter til å utføre en svært begrenset undersøkelse av restene av de avdøde.

Det de fant, var i korthet at den sannsynlige dødsårsaken var blyforgiftning, forårsaket av blyet som var i det loddetinnet som alle hermetikkboksene var forseglet med.

Det er synd at de ikke fikk anledning til å gjøre grundigere undersøkelser på stedet, for her hadde de altså levningene av 17 personer som åpenbart alle var døde av samme årsak. Eksponeringen hadde vært den samme. Boken om tragedien i Svenskhuset er spennende lesning. Den er veldokumentert, blant annet ved at sentrale kilder er gjengitt som vedlegg. Det er interessante illustrasjoner, blant annet samtidige fotografier. Boken er dessuten meget pen og delikat. Forfatterne har all ære av en fin bok! 